\title{
Effect of magnetic field on some biological and biochemical parameters of Earias insulana (Boisd.) (Lepidoptera: Noctuidae) \\ Saadiya M. Said ${ }^{1, ;}$ M. A. Kandil², and A. A. A. Abdelaal ${ }^{1 *}$ \\ ${ }^{1}$ Economic Entomology and Agriculture Zoology Department, Faculty of Agriculture, Menoufia University, Egypt \\ 2Plant Protection Research Institute, Agriculture Research Center, Dokki - Giza,Egypt
}

\section{ABSTRACT}

In this experiment, new technologies used to study the effects of two magnetic levels on longevity, fecundity and some biochemical parameters of Earias insulana adults. Two magnetic levels were used to produce a high magnetic field, (MF1) = (20.8 mt. in lower and $1.3 \mathrm{mt}$. in center jars) and another low, (MF2 $=(2.1 \mathrm{mt}$ in lower and $1.21 \mathrm{mt}$ in center) compared with non exposed adults (control). The results demonstrated that the total eggs laid /female and hatchability in exposed adults were highly significantly affected compared with control. Mean numbers of eggs laid/female were 77.0 and 109.6, when adults were exposed to MF1 and MF2, respectively, compared with 175.0 eggs/ female in control. The percentages of eggs hatchability were 49.6 and $79 \%$, in exposed adults to MF1 and MF2 respectively, compared with $95 \%$ in control. Data reported that exposure of adults to selected magnetic fields; MF1 and MF2 reduced the mean number of eggs /female. Percentages were $56 \%$ and $48.8 \%$ when exposed to high and low power (MF1and MF2) respectively. The results indicated that longevity of exposed females and males were significantly affected compared with control. Longevity of adult males decreased to about half the time when exposed to high powers MF1, the longevity of exposed males to MF1 and MF2 were 6.6 and 9.6 days/ male, respectively but it was 13.3 days/male in control. In females, the longevity decreased after exposure to the higher MF, whereas prorogated after exposure to the lower magnetic levels, the longevities of exposed females to MF1 and MF2 were 12.8 and 16.4 days / female respectively, compared with 15.8 days / female in control. In additions, the effects of exposure to the magnetic fields MF1 and MF2 on some biochemical parameters were determined. The results showed high decreased in levels of some key biochemical such as total proteins, total lipid, Free-amino acid and carbohydrates.

Key words: Earias insulana (Boisd.), magnetic field, biology and Biochemical analyses.

\section{INTRODUCTION}

In Egypt, the spiny bollworm (SBW), Earias insulana (Lepidoptera: Noctuidae) is considerable one of the most important pests attacking many plants especially, cotton, (Gossypium spp.). It is considered the $2^{\text {nd }}$ destructive pests of bollworms infesting cotton plants and causing severe damage resulting in high loss in both quantity and quality of the obtained yield (Amin and Foda, 1999). The magnetic field (MF), is considered one of many important environmental factors, has significant influence on living organisms. The influence of the MF becomes important which studied by many authors. Many researchs 
indicated that magnetic fields have highly effects on the development periods and viability of various insects (Said et. al., 2017). Static magnetic fields (SMF) acts as a type of environmental pressure that can make changes in some biological systems in insects. Arthur, (2003) and Ramirez et al., (1983) found that the eggs of Drosophila treated with low frequency of electromagnetic field (EMF) and static magnetic field (SMF) showed higher mortality than the control for all tested levels. Also, the same authors found that $1 \mathrm{mT}$ reduced the oviposition rates and increased the immature mortality rates. Shuai, (2014) recorded that the adults of Euproctis pseudoconspersa, highly affected when they were exposed to electromagnetic field. Also, longevity and fecundity of Ephestia kuehniella adults significantly decreased when adults were exposed to high levels of magnetic fluxes at LD50 magnetized. Also, Luechai, (2008) and Bualoi, (2009) recorded the different effects of the electromagnetic on all stages of some insects and its behavior.

Therefore, the aim of the present work aims to study the effects of two levels of magnetic flux on some biological and biochemical parameters of $E$. insulana adults.

\section{MATERIALS AND METHODS -Insect collection and rearing:}

Field strain $E$. insulana when collected from field and studied in laboratory at $26 \pm 1^{\circ} \mathrm{C}$ ) and $65-70 \%$ R.H. Different stages of spiny bollworm used in the current study were collected from cotton field Qaliubia Governorate during September to November of 2016 season and transferred to Bollworm Research Department, Plant Protection Research Institute, Agricultural Research Centre (ARC).
The SBW larvae and pupae collected from cotton fields, the larvae were fed separately on cotton bolls in glass jars $(1 / 2 \mathrm{~kg})$ covered with absorbent cotton wool. The food was daily renewed until pupation. Pupae were transferred to clean glass tubes and incubated until moth emergence. The emerged moths were sexed (5females $\times 5$ males) and caged. The moths were provided with $10 \%$ honey solution. The eggs were separated daily and placed in glass jars.

\section{-Adjusting and creating the magnetic field:}

The magnetic field was created by using a small similar magnet pieces. A glassy cylindrical container were used as a rearing boxes, and the magnet pieces were arranged $(\mathrm{S} / \mathrm{N}),(\mathrm{S} / \mathrm{N})$. Measurements were carried out in the center of the pre-mentioned cages as well as on the outer edge of these cages. Tow values of static magnetic field (SMF) were recorded; high value (MF1) (20.8 mT in lower and $1.3 \mathrm{mT}$ in center) and low value (MF2) (2.1 $\mathrm{mT}$ in lower and $1.21 \mathrm{mT}$ in center jars). The magnet pieces were measured with mille tesla meter apparatus (Faculty of Engineering Menofia University).

\section{-Latent effect of two magnetic flux on adults of $E$. insulana:}

This experiment, 45 adults (one day old) of $E$. insulana were divided into three groups, each group 15 individuals was replicated three times. The first group divided into 3 cages (each cages 5 pairs) and every cage exposed to magnetic flux (2.1 $\mathrm{mT}$ in lower and 1.21 $\mathrm{mT}$ in center jars), Examined under the previously mentioned rearing condition.

Second group: divided to three jars (each cage 15 adults), every cage exposed to high magnetic flux (20.8 mT in lower and $1.3 \mathrm{mT}$ in center)

The third group, the emerged moths resulted from field strain (without any 
treated) used as a control were sexed and transferred to chimney glass cage (5 pairs/cage). All cages fed on $20 \%$ sugar solution. Each cage was examined daily where the preoviposition, oviposition, postoviposition periods and longevity females and males for all treatment were recorded. Also, the total number of eggs per female was calculated from daily counts of deposited eggs. All experiments were carried out under laboratory conditions at $26 \pm 1{ }^{\circ} \mathrm{C}$ and $65-70 \%$ R.H.

\section{-Biochemical analysis:}

1. Preparation of samples for biochemical assay:

Five E. insulana; adults samples used for biochemical assays were collected at 5days after treatment of adult stage of $E$. insulana, with two magnetic field. The tested adults' samples were homogenized in distilled water. The homogenates were centrifuged at 5000 r.p.m. at $5 \mathrm{C}^{0}$ in refrigerated centrifuge. The supernatants' were kept in deep freezer at $-20 \mathrm{C}^{0}$ till use for biochemical assays. Larvae were analyzed chemically for each compound with untreated check in Physiological Dept. of plant Protection Researches Institute, (P.P.R.I.).

The colorimetric determination of total soluble protein as described by Bradford (1976). The total lipids were estimated by the method of Knight et al. (1972). Transaminase enzymes, A spartate amino transferase (AST) and alanine aminotransferase (ALT) enzyme activities were determined calorimetrically according to the method of Reitman and Frankle (1957).

The reaction mixture of enzyme assay according to Ishaaya and Swirski (1976). Phenoloxidase activity was determined according to modification of Ishaaya (1971).

\section{-Statistical analysis:}

Each treatment was replicated 3 times. Statistically analyzed values were expressed as mean \pm SE of replication and Student's t-test was applied to locate significant $(P, 0.05)$ differences between treated and control groups, (Snedecor, 1952, and Duncans (1957).

\section{RESULTS AND DISCUSSION}

\section{1-Effects of magnetic field on some biological parameters of $E$. insulana:}

Results in Table (1) showed that used magnetic field at (MF) two values high (FM1) and low (FM2) caused mortality, decreased in oviposition time, reduction in fecundity and fertility

\section{Pre- oviposition period:}

The obtained results in Table (1) indicate that the tested low magnetic value MF2 has no effect on the pre ovipostion period of $\boldsymbol{E}$. insulana significantly, but the effected appeared when the adult exposed to high magnetic. The pre- oviposition periods for SBW female were 4.2 and 2.9 days/female when adults exposed to MF1 and MF2, respectively, compared with 2.4 days/female in control.

\section{Oviposition period:}

Data recorded in Table (1) illustrated that the oviposition periods for SBW female lasted 6.3 and 10.3 days when treated with FM1 and FM2 respectively, opposed to 12.1 days in control, (Table 1). This data indicate that the high magnetic cussed high reduced in oviposition period (approximately to half time) compared with control. Ramirez, et. al. (1983) recorded decreased in oviposition and development time of Drosophila when treated by magnetic fields.

\section{Post oviposition:}

Also, data in Table (1) clear that the tested magnetic value has high 
significantly affected on the postovipostion period of $\boldsymbol{E}$. insulana when females exposed to high and low magnetic. The post oviposition periods were 4.1 and 2.3 and 3.3 days/female, when adults exposed to MF1 and MF2, respectively, compared with 1.3 days/female in control.

\section{Reproductive potential:}

Data presented in (Table 1) demonstrated that the high reduction in numbers of eggs laid by females was $77.0 \%$ eggs when females exposed to high MF (20.8 $\mathrm{mT}$ in lower and 3.1mT in center cage) and $89.6 \%$ eggs/ female with low magnetic compared with 175.0 eggs/ female in control. Pandir (2013) used a moderate intensity $\operatorname{SMF}(0,1.5,3,5,7.5$ and 10 $\mathrm{mT}$ ) to detect its biological effects on $E$. kuehniella adults. The longevity of adults, fecundity and daily egg production high decreased.

\section{Fecundity:}

In addition, the result in Table (1) recorded that the percentage of eggs hatchability were 49.6 and 79.0 , in female with high and lower magnetic pours, respectively, compared with 95.0 $\%$ in control. These resulted agree with Pan (1996) studied that the effects of a 7 Tesla of MFs on eggs hatching, he found the hatching of the eggs Tenebrio molitor $\mathrm{L}$ was delayed and hatching rate was reduced. In our study, when exposing the adults of $E$. insulana to high levels of MFs caused high reduction in daily and total eggs production with reduction in progeny production Pandir (2013).Also Said et al., (2017) recorded that the high significant effect of three levels of magnetic flux on reduction of eggs laid by pectinophra gossepiella.

\section{Adult stage}

Data in Table ( 1 ) percentages of adult emergence were 79.7 and 90.8 resulted from treated adults stage with MF1 (20.8 mt) and MF2 (2.1mt), respectively, while, the percentages increased to $98 \%$ adults emergence in control.

\section{Adult longevity}

The results indicated that female's and male longevity was highly significant affected when adults were exposed to high MF1, the longevity female (12.8 days / female while the longevity male decreased to half time (6.6 days ) compared to 13.3 days/ male in control. while, these period increased to 16.4 days /female and decreased to 9.0 days / male, when adults emergence exposed to low magnetic ( $2.1 \mathrm{mt}$ in lower and $1.21 \mathrm{mT}$ in center) compared with 15.8 days / female and 13.3 days / male for control . From this data can be concluded that the males high affected when exposed to magnetic in low or high than females. Pandir (2013) recorded that when used a moderate intensity $\operatorname{SMF}(0,1.5,3,5$, 7.5 and $10 \mathrm{mT}$ ) fond that effects on the longevity of Ephestia kuehniella adults. Martin et al., (1988) found that the used of static magnetic field reduced the life span adults' and flying activity of bees by $60 \%$ than control. Todorovic' et al., (2013) found that high effected the magnetic on behavior and longevity of Tenebrio molitor, Juan et al., (2012) recorded that the high effected of magnetic on fecundity and longevity on aphid.

\section{The incubation period of eggs:}

Data demonstrate in (Table 1) indicate that the time require to the eggs of spiny bollworm hatching was high significant affected by two treatment of high and low magnetic. 
Table (1): Effects of Two magnetic fields on longevity, fecundity and fertility for adults' of $E$. insulana field strain

\begin{tabular}{|c|c|c|c|c|c|c|c|}
\hline \multirow{2}{*}{$\begin{array}{l}\text { Levels of } \\
\text { magnetic } \\
\text { flux }\end{array}$} & \multirow{2}{*}{$\begin{array}{c}\text { Pre- } \\
\text { oviposition }\end{array}$} & \multirow[b]{2}{*}{ Oviposition } & \multirow{2}{*}{$\begin{array}{c}\text { Post- } \\
\text { ovipostion }\end{array}$} & \multicolumn{4}{|c|}{ Fecundity and fertility of $E$. insulana field strain (adults) } \\
\hline & & & & $\begin{array}{c}\text { Total eggs laid / } \\
\text { female }\end{array}$ & $\underset{\%}{\text { Reduction }}$ & $\begin{array}{c}\text { Hatchability } \\
\%\end{array}$ & $\begin{array}{c}\text { Reduction } \\
\%\end{array}$ \\
\hline High MF1 & $4.2 \pm 0.2 \mathrm{a}$ & $\mathbf{6 . 3} \pm 0.9 \mathbf{b}$ & $2.3 \pm 0.4 \mathrm{a}$ & $77.0 \pm 3.6 \mathrm{c}$ & 56 & 49.6 & 47.7 \\
\hline Low MF2 & $2.9 \pm 0.1 b$ & $\mathbf{1 0 . 3} \pm 1.4 \mathbf{a}$ & $3.3 \pm 0.5 . b$ & $109.6 \pm 2.1 b$ & 48.8 & 79 & 16.8 \\
\hline Control & $2.4 \pm 0.2 \mathrm{c}$ & $12.1 \pm 0.6 \mathbf{a}$ & $1.3 \pm 0.1 \mathrm{c}$ & $175.0 \pm 2.7 \mathrm{a}$ & --- & 95 & 5 \\
\hline LSD 5\% & 0.102 & 2.331 & 0.144 & 3.116 & ---- & 4.235 & ----- \\
\hline $\begin{array}{c}\text { Level of } \\
\text { magnetic } \\
\text { flux }\end{array}$ & $\begin{array}{c}\text { Longevity } \\
\text { female/ } \\
\text { time in days }\end{array}$ & $\begin{array}{c}\text { Longevity } \\
\text { male/ time in } \\
\text { days }\end{array}$ & $\begin{array}{c}\text { Incubation } \\
\text { times of } \\
\text { eggs }\end{array}$ & \multicolumn{4}{|c|}{$(+)$ increase in times of eggs } \\
\hline High MF1 & $12.8 \pm 1.3$ & $6.6 \pm 0.5$ & $5.3 \pm 0.6 \mathrm{a}$ & \multicolumn{4}{|c|}{+1.6 times } \\
\hline Low MF2 & $16.4 \pm 1.1$ & $9.0 \pm 0.6$ & $4.6 \pm 0.2 b$ & \multicolumn{4}{|c|}{+1.39 times } \\
\hline Control & $15.8 \pm 0.7$ & $13.3 \pm 0.8$ & $3.3 \pm 0.1 \mathrm{c}$ & \multicolumn{4}{|c|}{---} \\
\hline LSD5\% & 0.225 & 1.114 & 0.011 & \multicolumn{4}{|c|}{------ } \\
\hline
\end{tabular}

Means followed by same letter in columns are not significantly different at $5 \%$ level by t-test

Results are presented as mean \pm SD of 3 replicates

MF1, high magnetic $=(20.8 \mathrm{mt}$. in lower and $1.3 \mathrm{mt}$. in center jars $) \cdot \mathrm{MF} 1$, low magnetic $=(2.1 \mathrm{mt}$. in lower and $1.21 \mathrm{mt}$. in center jars).mt, mele Tesla (unit of magnetic field). Tesla: magnetic field unit.

Table (2): Effects of exposure of E. insulana adults field strain to two levels of magnetic flux on some Biochemical parameters.

\begin{tabular}{|c|c|c|c|c|c|}
\hline \multirow{2}{*}{ Biochemical Parameters } & \multicolumn{2}{|c|}{ Level of magnetic flux } & \multirow{2}{*}{$\begin{array}{l}\text { Untreated } \\
\text { (Control) }\end{array}$} & \multirow{2}{*}{$\begin{array}{l}\text { Change } \\
\text { relative of } \\
\text { control\% }\end{array}$} & \multirow[t]{2}{*}{ LSD 5\% } \\
\hline & High MF(MF1) & Low MF (MF2) & & & \\
\hline Total protein (mg/g.b.wt) & $11.31 \pm 0 \mathrm{~b}$ & $16.17 \pm 0.38 \mathrm{a}$ & $17.67 \pm 0.47 \mathrm{a}$ & $35.99-8.5$ & 2.113 \\
\hline $\begin{array}{c}\text { Free-amino acids( } \mu \mathrm{g} \text { D,L- } \\
\text { alanine/g.b.wt) }\end{array}$ & $216.60 \pm 7.25 \mathrm{c}$ & $336.33 \pm 6.73 b$ & $560.0 \pm 16.88 \mathrm{a}$ & $61.32-39.9$ & 6.142 \\
\hline $\begin{array}{c}\text { Total carbohydrate } \\
\text { (mg/g.b.wt) }\end{array}$ & $6.5 \pm 0.3 \mathrm{c}$ & $18.2 \pm 0.4 \mathrm{~b}$ & $31.0 \pm 1.1 \mathrm{a}$ & $41.3-79.0$ & 2.624 \\
\hline Total lipid (mg/g.b.wt) & $9.05 \pm 0.33 \mathrm{c}$ & $11.6 \pm 2.21 \mathrm{~b}$ & $15.33 \pm 3.22 \mathrm{a}$ & $59.03-24.33$ & 1.021 \\
\hline $\begin{array}{c}\text { Aspartate amino } \\
\text { transferase (AST/GOT) } \\
\left(\mathrm{U} \times \mathbf{1 0}^{3} / \mathrm{g} . \text { b.wt }\right)\end{array}$ & $1299.0 \pm 31.5 \mathrm{c}$ & $1462.66 \pm 24.2 \mathrm{~b}$ & $1587.0 \pm 36.35 \mathrm{a}$ & $18.14-7.88$ & 12.651 \\
\hline $\begin{array}{c}\text { Alanine amino transferase } \\
\text { (ALT/GPT) } \\
\left(\mathrm{U} \times \mathbf{1 0}^{3} / \text { g.b.wt) }\right.\end{array}$ & $997.6 \pm 15.9 \mathrm{~b}$ & $\begin{array}{c}1131.67 \pm 24.38 \\
\mathrm{a}\end{array}$ & $1178.33 \pm 47.77 \mathrm{a}$ & $11.84-3.96$ & 78.512 \\
\hline $\begin{array}{c}\text { Phenoloxidase } \\
\text { (O.D. units/g.b.wt) }\end{array}$ & $1.30 \pm 0.05 \mathrm{~b}$ & $1.93 \pm 0.1 b$ & $4.63 \pm 0.2 \mathrm{a}$ & $71.92-58.31$ & 0.821 \\
\hline
\end{tabular}

Means followed by the same letter in rows are not significantly different at $5 \%$ level by T-test.

Results are presented as mean $\pm \mathrm{SD}$ of 3 replicates

MF1, high magnetic $=(20.8 \mathrm{mt}$. in lower and $1.3 \mathrm{mt}$. in center jars $)$.

MF1, low magnetic $=(2.1 \mathrm{mt}$. in lower and $1.21 \mathrm{mt}$. in center jars $)$.

$\mathrm{mt}$, mele Tesla (unit of magnetic field). Tesla: magnetic field unit. 
These incubation period estimated by 5.3 and 4.6 days when eggs resulted from treated with high and low magnetic, respectively compared with 3.3 days for control, this data indicated that when eggs resulted from adults treated by the two tested magnetic, the incubation period of eggs increased to 2 -2.5time than control.

\section{2-Biochemical analyses:}

The results presented in Table (2) indicated that the examined magnetic levels significantly affected the levels of total proteins, lipids carbohydrates and free amino acids which contents in the insect, and which very necessary to energy and fecundity in adult stage compared with the control. the levels of total protein decreased to 11.31 and $16.17 \mathrm{mg} / \mathrm{g} . b . w t$, with high and low magnetic total free amino acids 216.6 and $336.33 \mathrm{mg} / \mathrm{g}$. b. wt with high and low magnetic, respectively compared to 560.0 in control and lipid (15.33 $\mathrm{mg} / \mathrm{g}$. b.wt) were found in control, to be decreased in the hemolymph in high magnetic treated to $11.31,216.6$ and $9.05 \mathrm{mg} / \mathrm{g}$. b. wt, in protein, aminoaside and lipid, respectively, but in low MF treated these value were 16.17 $\mathrm{mg} / \mathrm{g}$. b. wt, in protein, $336.33 \mathrm{mg} / \mathrm{g}$. b. $\mathrm{wt}$, in free amino acids and $11.6 \mathrm{mg} / \mathrm{g}$. b. wt, in lipid, Table,3. However, only the high decrease was observed in the levels of total carbohydrates approximately decreased to 5 times (6.5 mg/g. b. wt) at high MF, compared to 31.0 in control.

Data summarized in Table (2) shows the trans-aminases like the enzyme activities GOT and GPT high decrease under MF condition. When compared with the control the activities of the enzymes GOT and GPT high decreased to 1299.0 and 997.6 ( $U$ x $10^{3} /$ g.b.wt)in the hemolymph of $E$. insulana adults when exposed to high magnetic, respectively, compared with 1587.0 and 1178.33 , respectively in control. The both trans-aminases GOT and GPT which have an important role in protein synthesis were high reduction in the adults stage, at the same time, the Phenoloxidase take the same trend, The percentage decrease in Phenoloxidase was very high affected when exposed $E$. insulana adults to MF, estimated by 1.3 and 1.93 (O.D. units/g.b.wt) compared with 4.63(O.D. units/g.b.wt) in control. Yim and Jeong, (2006) demonstrated the relatively strong biological effects of MFs on the modulation of ion fowl interference with DNA synthesis and RNA transcription; thus affecting the composition of amino acids and protein formation. (Jia et al., 2009) recorded the effect of MF on reduced $\alpha$-amylase activity.

\section{CONCLUSION}

Magnetic field may be plays a major role in some biological and physiological aspects in insects .The presented results concluded that magnetic flux induced changes in the dynamics of all examined adult. Data recorded highly significantly affect adults of $E$. insulana when exposed to the (high MF) reflected recorded high effects on decreased the duration stage of adults males (longevity), at the same time this effected appeared in high significant highly redaction in daily egg laying and fecundity of magnetized females comparison with control, this reduction due to the reduce in total protin and carbohydrate.

\section{ACKNOWLEDGEMENT}

Thanks to the Dr. Prof. Abd El Khaleq Husseen; Professor of Acarology Plant Protection Research Institute Agricultural Research Center for his efforts in the measurement of the magnetic field of magnetic parts used in this research in the Faculty of Engineering in Shebin El-Kom ,Monoufia University . 


\section{REFERENCES}

Amin A. A. H. and M. E. Foda (1999). Field-based, degree-day model for spiny bollworm Earias insulana development. Proceeding Beltwide Cotton Conferences, pp. 923-925.

Arthur D. R. (2003). Mechanism of action of moderate- intensity static magnetic felds on biological systems. Cell Biochem Biophys. 39, 162-173.

Bradford M. M. (1976). A rapid and sensitive method for the quantization of microgram quantities of protein utilizing the principle of protein-dye binding. Anal. Biochem., 72: 248-254

Bualoi K. (2009). Using radio frequency to control red flour beetle Tribolium castaneum (Herbst) (Coleoptera: Tenebrionidae) in feed. Master's thesis. Chiang Mai University, Chiang Mai, Thailand.

Duncan D. B. (1955). Multiple ranges and multiple $\mathrm{F}$ test. Biometrics. 11:1-42.

Ishaaya I. (1971). Observation on the phenoloxidase system in the armored scale

Aonidiellaaurantiiand

Chrysomphalusaonidum. Comp. Biochem .Physiol ., 39 B, 935-943.

Ishaaya I. and E. Swirski (1976). Trehalase, invertase and amylase activities in the black scale Saissetiaoleae, and their relation to host adaptability. J. Insect Physiol. 22: 1025-1029.

Jia S. Y., Liu, Y., Wang, S. H., and Z. B. Wang (2009). Effect of static field on $\alpha$-amylase activity and enzymatic reaction. Transactions of Tianjin University. 15, 272-275.

Juan H.G.; H. Yan; W. Monika; H. U. ZU-Aing and $\mathrm{H}$. U. Xiang-Shun
(2012).Effect of static magnetic field (SMF) on the viability and fecundity of aphid Sitobion avenae (Homoptera: Aphididae) under laboratory conditions. Arch. Biol. Sci., Belgrade, 64 (2), 693-702, 2012

Knight J.A., S. Anderson and J.M. Rawle (1972). Chemical basis of the sulfo-phospho-vanillin reaction for estimating total serum lipids.Clin. Chem., 18:199-202.

Luechai N. (2008). Radio frequency treatment for controlling rice moth, Corcyra cephalonica (Stainton) and its effects on quality of milled rice cv Khao Dawk Mali 105. Master's thesis. Chiang Mai University, Chiang Mai, Thailand.

Martin H., H. Korall and B. Forster (1988). Magnetic field effects on activity and aging in honeybees. J. Comp Physiol. 164, 423-431.

Pan H. (1996). The effect of a $7 \mathrm{~T}$ magnetic field on the egg hatching of Heliothis virescens. Magnetic Resonance Imaging, 14(6): 673677.

Pandir D., S. E. Fahriye and S. Recep (2013) Assessment of the influence of magnetic fields on aspects of the biology of the adult Mediterranean flour moth Ephestia kuehniella Zeller, $1879 \quad$ (Lepidoptera: Pyralidae). Türk. entomol. derg., 2013, 37 (4): 423-431.

Reitman S. M. and S. Frankel (1957). A colorimetric method for determination of serum glutamic pyruvic transaminase. Am. J. Clin. Path., (28):56-63. 
Ramirez E., J.L. Monteagudo, M. G. Gracia and J.M. Delgado (1983). Oviposition and development of Drosophila modified by magnetic fields. Bioelectromagnetics, 4(4): 315-326.

Said, S. M., M. A. Kandel and A. M. Matar (2017) .Interaction of Magnetic flux with some biological aspects of Pectinophora gossypiella (Saunders).Bull. ent. Soc. Egypt, Econ. Ser., 43,(17-30).

Shuai C., H. Jia , X. Xie , J. Yao1 and L.V. Feng (2014). Effect of electromagnetic exposure at difference frequencies on euproctis pseudoconspersa's growth and development at different stages. Journal of Chemical and Pharmaceutical Research, 2014, 6(4):1072-1076 .
Snedecor G.W. (1952). Statistical methods $5^{\text {th }}$ Ed. lowa State Col.N.Y. Preparation of samples for biochemical assay.

Todorovic'D. , T. Markovic' , Z. Prolic' S Mihajlovic' , S. Rauš ,L. Nikolic'and B. Janac' (2013). The influence of static magnetic field (50 mT) on development and motor behavior of Tenebrio (Cleoptra : Tenebrionidae). Inter. J. of Radiation Biology, January 2013; 89(1): 44-50

Yim S. H. and J. H. Jeong (2006). Environmental magnetic felds and its biological effects. Kor. J. Gerontol. 16, 6-10. 